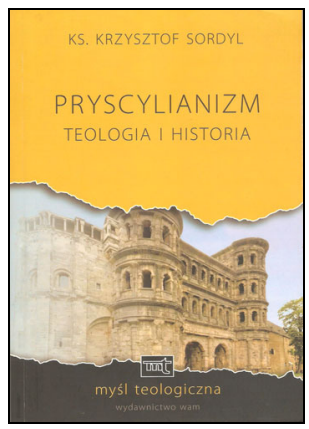

\title{
Dariusz Spychała \\ (Bydgoszcz) \\ MIĘDZY ORTODOKSJĄ, HEREZJĄ A POLITYKĄ, CZYLI NIEZBYT UDANA PRÓBA REKONSTRUKCJI DZIEJÓW I POGLĄDÓW PRYSCYLIAN
}

Krzysztof Sordyl, Pryscylianizm. Teologia i historia, Wydawnictwo WAM, Kraków 2015, ss. 428

W znanym krakowskim jezuickim wydawnictwie WAM w ramach ukazującej się w tej oficynie naukowej serii „Myśl Teologiczna” wydano w 2015 r. kolejną pracę poświęconą zagadnieniom początków chrześcijaństwa, a dokładniej jednego z jego nurtów, czyli w tym przypadku pryscylianizmu. Autor tej monografii, dr Krzysztof Sordyl, jest patrologiem specjalizującym się dotychczas w twórczości tak różnych osobowości, jak Jan z Damaszku i Nowacjan². Należy z uznaniem

\footnotetext{
${ }^{1}$ Redaktorami wspomnianej serii są Arkadiusz Baron i Henryk Pietras. Jeżeli chodzi o tematykę zamieszczanych w jej ramach dzieł, można wspomnieć następujące prace: L. Padovese, Wprowadzenie do teologii patrystycznej, tłum. A. Baron, Myśl Teologiczna (=MT) 1, Kraków 1994; P.P. Gilbert, Wprowadzenie do teologii średniowiecznej, tłum. T. Górski, MT 12, Kraków 1997; J.A. Fitzmyer, Pismo duszą teologii, tłum. A. Baron, M. Dobrzyniak, R. Robak, MT 14, Kraków 1997; M. Simonetti, Między dosłownością a alegorią, Przyczynek do historii egzegezy patrystycznej, tłum. T. Skibiński, MT 26, Kraków 2000; H. Pietras, Początki teologii Kościoła, MT 28, Kraków 2000; M. Gilbert, Mądrość Salomona, 1, tłum. S. Kobiałka, MT 37, Kraków 2002; idem, Mądrość Salomona, 2, tłum. S. Kobiałka, MT 38, Kraków 2002; J. Daniélou, Teologia judeochrześcijańska. Historia doktryn chrześcijańskich przed soborem nicejskim, tłum. S. Basista, MT 39, Kraków 2002; A. Jankowski, Rozwój chrystologii Nowego Testamentu, MT 46, Kraków 2005; F. Szulc, Struktura teologii judeochrześcijańskiej. Studium metodologiczne w świetle badań J. Daniélou, MT 47, Kraków 2005; A. Baron, Neoplatońska idea Boga a ewangelizacja. Analiza anonimowego komentarza do „Parmenidesa” Platona na tle myśli plotyńsko-porfiriańskiej, MT 50, Kraków 2005; H. Pietras, Eschatologia Kościoła pierwszych czterech wieków, MT 55, Kraków 2007; Ch. Dohmen, G. Stemberger, Hermeneutyka Biblii żydowskiej i Starego Testamentu, tłum. M. Szczepaniak, MT 59, Kraków 2008; A. Muszala, Embrion ludzki w starożytnej refleksji teologicznej, MT 63, Kraków 2009; P.M. Szewczyk, Człowieczeństwo Logosu według Atanazego Wielkiego, MT 65, Kraków 2010; H. Pietras, Sobór nicejski (325). Kontekst religijny i polityczny. Dokumenty i komentarze, MT 74, Kraków 2013; A. Baron, Świętość a ideały człowieka. (Ojcowie Apostolscy, Klemens Aleksandryjski, Orygenes). Studium teologiczne na tle modeli filozoficznoreligijnych, MT 79, Kraków 2013; A.N. Williams, Boski zmysł. Intelekt w teologii patrystycznej, tłum. W. Dawidowski, MT 82, Kraków 2014.

${ }^{2}$ Pierwsze z wymienionych dzieł to praca magisterska zatytułowana „Bóg i tajemnica człowieka. Studium «Wykładu wiary prawdziwej» Jana z Damaszku” została napisana na PAT w Krakowie
} 
podkreślić szerokość zainteresowań tego historyka, który cierpliwie zgłębiał, raczej z powodzeniem, epoki tak odmienne pod względem historycznym, jak III i VII-VIII w. po Chrystusie. Wydawało się więc, że nie sprawi większych problemów autorowi, szczególnie po specjalistycznych studiach w rzymskim Instytucie Patrystycznym „Augustinianum” i po pracowitym pogłębieniu znajomości odpowiedniej dla tematu hiszpańskojęzycznej literatury naukowej, opisanie wydarzeń związanych z wystąpieniem i nauczaniem Pryscyliana.

Recenzowana praca przedstawia wydarzenia związane $\mathrm{z}$ powstaniem i trwaniem pryscylianizmu (ruchu religijnego zapoczątkowanego przez Pryscyliana), czyli okres od 2. poł. IV w. do początków VII w. (z pewnymi nawiązaniami do faktów poprzedzających podany zakres chronologiczny i wydarzeń wykraczających poza podane ramy). Sam autor zauważa, że metodą, jaką kierował się przy porządkowaniu materiału, jest „metoda interdyscyplinarna podporządkowana zasadzie wnioskowania do najlepszego wyjaśnienia”. Brzmi to niewątpliwie bardzo naukowo. Dla ułatwienia sobie pracy Krzysztof Sordyl podzielił wspomnianą metodę na części: teologiczną, filologiczną i historyczno-porównawczą. Recenzentowi wydaje się jednak, że sposób przedstawiania przez niego materiału nawiązuje przede wszystkim przy tematyce historycznej do klasycznego, chronologicznego sposobu przedstawiania wydarzeń i do ukazywania pozostałych, zgodnie z klasyczną metodą problemową. Terytorialnie obiektem zainteresowań Sordyla jest obszar rzymskiej Hiszpanii i Galii z nielicznymi nawiązaniami do pozostałych terenów Cesarstwa.

Autor podzielił swoją monografię na następujące części: wprowadzenie, pięć rozdziałów, podsumowanie, skróty, bibliografię, streszczenie w języku angielskim, indeksy: osób i cytowanych źródeł. We wprowadzeniu przedstawia wykorzystaną przez siebie literaturę naukową i źródła do tego zagadnienia, które zostały zebrane w miarę kompletnie, choć zadziwia brak w sporządzonym zestawieniu takich źródeł antycznych, jak: Pawła Orozjusza „Historia przeciw poganom”, „Kronika” Hieronima ze Strydonu, „Historia Kościoła” Rufina z Akwilei, „Historia Kościoła” Teodoreta z Cyru, „Historia Rzymska” Pawła Diakona czy praca Juliusza Firmicusa Maternusa zatytułowana "Jak nieświadomi błądzą w wierze”. Dla

w 1999 r.; kolejna to „Pojęcie Boga w De Trinitate. Polemiczne aspekty teologii Nowacjana»”, wydana przez Wydawnictwo WAM, w Krakowie w 2007 r.

${ }^{3}$ Firmicus Maternus, De Erorre Profanarum Religionum, PL 12, col. 981-105012, col. 981-1050; idem, Jak nieświadomi błądzą w wierze, tłum. B. Gaj, Warszawa 2015; Hieronymus, Die Chronik, rec. R. Helm, Berlin 1956; Orosius, Historiae adversum paganos, C. Zangemeister (red.), CSEL 5, Wien 1882; idem, Historia przeciw poganom, tłum. H. Pietruszczak, Zgorzelec 2015; P. Diaconi, Historia Romana, [w:] A. Crivellucci (red.), Fonti per la storia d'Italia 51, Roma 1914; idem, Historia rzymska. Historia Longobardów, przeł. I. Lewandowski, Warszawa 1995; Rufini 
znajomości na Zachodzie egipskiego życia monastycznego przydałaby się również lektura „Pierwszego dialogu” Sulpicjusza Severa ${ }^{4}$. Ukazany przez galijskiego pisarza obraz monastycyzmu egipskiego nie wydaje się bowiem zbieżny z przekazem Krzysztofa Sordyla, który zdecydowanie podkreśla umiarkowanie tego ruchu. Zapoznanie się z treścią tych prac, szczególnie Hieronima, Orozjusza, Rufina, Teodoreta i Pawła Diakona, ułatwiłoby autorowi również zrozumienie politycznych uwarunkowań, w których działał Pryscylian. Jeszcze większe wątpliwości niż dobór źródeł budzi zestawienie literatury naukowej wykorzystanej do napisania recenzowanej monografii. $Z$ autorów zagranicznych brak np. Petera Browna, Gilliany Clark, Aleksandra Demandta, Hubertusa R. Drobnera, Michaela Fiedrowicza, Williama Harmlessa, Rabana Haehlinga von Linzenauera, Gerta Haendlera, Bernarda McGinna, Adolfa Lippolda, Jochena Martina, Santo Mazzarino, Stefana Rebenicha, Christiana Schweizera, podstawowej pracy Manlio Simonettiego, dzieł: Marty Sordi, Reinera Sörriesa, Raymonda Van Dama, Josepha Vogta, Maurice’a Wilesa ${ }^{5}$ i wielu innych. Ich znajomość pozwoliłaby

Aquileiensis, Historiae Ecclesiasticae, libri duo, PL 21, Pariisis 1845, col. 465-539; Theodoret, Historia ecclesiastica, PG 82, col. 882-1280.

${ }^{4}$ Sulpicii Severii, Dialogus Primus, [w:] idem, Libri qui supersunt, rec. C. Halm, Vindobonae 1866, CSEL 1, s. 152-180.

${ }^{5}$ P. Brown, Augustyn z Hippony, tłum. W. Radwański, BSL, Warszawa 1993; idem, Ciało i społeczeństwo. Mężczyźni, kobiety i abstynencja seksualna we wczesnym chrześcijaństwie, tłum. I. Kania, Kraków 2006; idem, Kult świętych. Narodziny i rola w chrześcijaństwie łacińskim, tłum. J. Partyka, Kraków 2007; G. Clark, Christianity and Roman society, Cambridge, bdw.; A. Demandt, Die Spätantike. Römische Geschichte von Diocletian bis Justinian 284-565 n. Ch., München 1989; idem, Kaisertum und Reichsidee in der Spätantike, [w:] C. Colpe, L. Honnefelder, M. Lutz-Bachmann (red.), Spätantike und Christentum. Beiträge zur Religions- und Geistesgeschichte der griechisch-römischen Kultur und Zivilisation der Kaiserzeit, Berlin 1992, s. 9-22; H.R. Drobner, The Fathers of the Church. A comprehensive introduction, tłum. S. Schatzmann, Peabody 2007; M. Fiedrowicz, Teologia ojców Kościoła, Podstawy chrześcijańskiej refleksji nad wiarą, tłum. W. Szymona, Kraków 2009; idem, Apologie im frühen Christentum. Die Kontroverse um den christlichen Wahrheitsanspruch in den ersten Jahrhundret, Paderborn-München-Wien-Zürich 2000; W. Harmless, Chrześcijanie pustyni. Wprowadzenie do literatury wczesnego monastycyzmu, tłum. M. Höffner, Kraków 2009; R. Haehling von Lanzenauer, Die Religionszugehörigkeit der hohen Amtsträger des Römischen Reiches seit Constantins I. Alleinherrschaft bis zum Ende der Theodosianischen Dynastie (324-450 bzw. 455 n. Chr.), Antiquitas 3, IV, Abhandlungen zur Vor- und Frühgeschichte, zur klassischen und provinzial-römischen. Archäologie und zur Geschichte des Altertums, 23, Bonn 1978; idem, Die römische Frühzeit in der Sicht frühchristlicher Autoren, [w:] idem, Rom und das himmlisch, Antiquitas 3, IV, s. 184-204; idem, Zwei Fremde in Rom: Das Wunderduell des Petrus mit Simon Mag in den acta Petri, RQAKG 1-2/98/2003, s. 47-71; G. Haendler, Von Tertullian bis zu Ambrosius. Die Kirche im Abendland vom Ende des 2. bis zum Ende des 4. Jahrhunderts, Kirchengeschichte in Einzeldarstellungen I/3, Berlin 1978; idem, Die abendländische Kirche im Zeitalter der Völkerwanderung, Kirchengeschichte in Einzeldarstellungen, Berlin 1980; B. McGinn, Obecność Boga. Historia mistyki zachodniochrześcijańskiej, Fundamenty mistyki, 1, tłum. T. Dekert, Kraków 2009; A. Lippold, Theodosius der Grosse und seine Zeit, München 1980; idem, Theodosius der Grosse, [w:] RKA, 
autorowi umieścić przedstawiane wydarzenia historyczne związane $\mathrm{z}$ powstaniem i rozwojem pryscylianizmu na odpowiednim, rzeczywistym tle. Mimo całego szacunku dla poziomu specjalistycznej hiszpańskiej literatury naukowej, którą autor obficie wykorzystał, należy pamiętać o tym, że istnieją również inne obszary naukowej działalności i warto byłoby wyważyć odpowiednie proporcje przygotowywanej na potrzeby pracy literatury. Jak się jednak wydaje, Krzysztof Sordyl przy doborze swojej bibliografii kierował się przede wszystkim dość prostym kryterium, czyli tytułami dzieł i artykułów, co nie zawsze jest metodą wystarczającą. Potwierdza to przykład z polską bibliografią pryscyliańską, do której to zaliczone zostały dzieła: Marka Starowieyskiego, Piotra Stacha, Tadeusza Kołosowskiego, Kazimierza Obryckiego, Piotra Liszki, Piotra Szczura i samego Krzysztofa Sordyla. Autor nie zauważył pracy Sławomira Bralewskiego o stosunku cesarzy do synodów biskupów oraz monografii Kazimierza Ilskiego, niezbędnej dla zrozumienia polityki biskupa Ambrożego i działalności Magnusa Maksymusa, dzieł Michała Stachury zajmującego się herezjami w okresie późnej starożytności, pracy Jerzego Strzelczyka poświęconej Gotom, monografii Dariusza Spychały czy monumentalnej syntezy Ewy Wipszyckiej, podając tylko część z całej listy publikacji, które mogłyby trafić do sporządzonego na potrzeby recenzowanej pracy spisu literatury naukowej.

Sup. XIII, Stuttgart 1972, s. 1-125; J. Martin, Spätantike und Völkerwanderung, OGG, 4, München 1987; S. Mazzarino, Storia sociale del vescovo Ambrogio (Problemi e ricerche di storia antica 4), Roma 1989, szczególnie s. 47-61 i 66-71; S. Rebenich, Hieronymus und sein Kreis. Prosopographische und sozialgeschichtliche Untersuchungen, Stuttgart 1992; Ch. Schweizer, Hierarchie und Organisation der römischen Reichskirche in der Kaisergesetzgebung vom vierten bis zum sechsten Jahrhundert, Europäische Hochsulschriften, 479, Bern-Berlin-Frankfurt am M. 1991; M. Simonetti, La crisi ariana nel IV secolo, Studia ephemeridis Augustianum, Roma 1975; M. Sordi, La concezione politica di Ambrogio, [w:] G. Bonamente, A. Nestore (red.), I Cristiani e l'Imperio nel IV secolo. Colloquio sul Cristianesimo nel mondo antico, Macerata 1988, s. 143-154; R. Sörries, Auxentius und Ambrosius. Ein Beitrag zur frühchristlichen Kunst Mailands zwischen Häresie und Rechtgläubigkeit, (Christliche Archäologie, Bd. 1), Dettelbach 1996; R. Van Dam, Saints and their miracles in late antique Gaul, Princeton 1993; J. Vogt, Upadek Rzymu, tłum. A. Łukaszewicz, Warszawa 1993; M. Wiles, Archetypal Heresy. Arianism trough the Centuries, Oxford 1996.

${ }^{6}$ S. Bralewski, Imperatorzy późnego Cesarstwa Rzymskiego wobec zgromadzeń biskupów, Byzantyna Lodziensia 1, Łódź 1997; K. Ilski, Idea jedności politycznej, społecznej i religijnej w świetle pism Ambrożego z Mediolanu, Historia, 196, Poznań 2001; D. Spychała, Cesarze rzymscy a arianizm od Konstantyna Wielkiego do Teodozjusza Wielkiego, 312-395 r., Poznań 2007; idem, Przemiany religijne i kulturowe w zachodnich prowincjach Cesarstwa Rzymskiego od roku 306 do śmierci św. Augustyna, 1-2, Bydgoszcz 2016; M. Stachura, Heretycy, schizmatycy i manichejczycy wobec cesarstwa rzymskiego (lata 324-428, wschodnia część Imperium), Kraków 2000; idem, Wrogowie porządku rzymskiego. Studium zjawiska agresji językowej w Kodeksie Teodozjusza, Nowelach Postteodozjańskich i Konstytucjach Sirmondiańskich, Kraków 2010; J. Strzelczyk, Goci - rzeczywistość i legenda, Warszawa 1984; E. Wipszycka, Kościół w świecie późnego antyku, Warszawa 1994, szczególnie s. 166-168. 
Wspomniane braki $\mathrm{w}$ tego typu literaturze są widoczne $\mathrm{w}$ znacznej części omawianej pracy, szczególnie gdy autor próbuje przedstawić tło, na którym toczy się konflikt wywołany przez nauczanie Pryscyliana. W pierwszym rozdziale, kiedy autor ukazuje dyskusję nad źródłami związanymi z Pryscylianem i jego zwolennikami, szczególnie przy okazji rozpatrywania problemów zawartości doktrynalnej spornych pod względem autorstwa "Traktatów”, czyni to niewątpliwie w sposób zasługujący na pochwałę. Niestety inaczej jest przy próbach powiązania referowanego materiału $\mathrm{z}$ wydarzeniami historycznymi. Na przykład już na s. 74 swojej pracy, ukazując przebieg uzurpacji Magnusa Maksymusa na przykładzie „Panegyricusa” Latinusa Paktusa, Krzysztof Sordyl zauważa, że „autor wychwala w nim zwycięstwo Teodozjusza nad uzurpatorem Maksymusem, który opuścił Brytanię, a kilka lat wcześniej zrzucił Gracjana z tronu cesarskiego". Taki przebieg wypadków pozostawiony bez komentarza jest błędny, gdyż jak powszechnie wiadomo, dopiero po opuszczeniu wyspy Magnus pokonał syna Walentyniana $\mathrm{I}^{7}$. W kolejnym rozdziale poświęconym historii pryscylianizmu na s. 102 zbyt jednoznacznie powiązał on postanowienia synodu w Rimini $\mathrm{z}$ arianizmem, gdy tymczasem decyzje tego synodu wyraźnie ukazują, że dominował w czasie jego obrad, a szczególnie w dokumentach końcowych, zgodnie z wolą Konstancjusza II, homeizm, który z nauką Ariusza nie miał wiele wspólnego ${ }^{8}$. Podobnie zbyt zagmatwany styl autora spowodował niejasność kolejnego wywodu, tym razem na s. 116 i 117, z którego ma wynikać istnienie procedury przyjmowania do Kościoła zwolenników wspomnianego wyżej synodu, czyli zdaniem autora - $\operatorname{arian}^{9}$. Może i tak było w Kościele hiszpańskim, ale niestety dla Krzysztofa Sordyla stronnicy wyznania wiary uchwalonego na tymże zgromadzeniu hierarchów nie byli, jak powtórnie twierdzi, arianami, lecz homejczy-

${ }^{7}$ P. Diak. HR, XI. 16-17; Soc. HE, V. 11; Soz. HE, VII. 13; Teod. HE, V. 12; Zos. His. IV. 35; A. Demandt, Die Spätantike, s. 129, sugeruje, że uzurpator ów mógł być spokrewniony z Teodozjuszem; K. Ilski, Idea jedności politycznej, społecznej i religijnej, s. 113, zauważa, że Maksymus podniósł bunt w Brytanii wiosną 383 r., a następnie opuścił wspomnianą wyspę, udając się do Galii. Gracjan został pokonany dopiero w sierpniu tegoż roku; J. Martin, Spätantike und Völkerwanderung, s. 36; D. Spychała, Cesarze, s. 129.

${ }^{8}$ Ariminum (359) can. 1, 3-11, [w:] A. Baron, H. Pietras (red.), Acta Synodalia ann. 50-381. Dokumenty synodów od 50 do 381 roku, Synodi et Collectiones Legum, 1; Źródła Myśli Teologicznej 37, Kraków 2006, s. 228; Soc. II. 37; Soz. IV. 23-24; Sulp. Sev. Chron. II. 41; Teod. HE, II. 18-20, 22-23; S. Bralewski, Imperatorzy późnego Cesarstwa Rzymskiego, s. 31; M. Simonetti, La crisi, s. 314-325; D. Spychała, Cesarze, s. 36-40, 114, 178-180.

${ }^{9}$ Ariminum (359) can. 1, 3-11; Soc. II. 37; Soz. IV. 23-24; Teod. HE, II. 18-20, 22-23; S. Bralewski, Imperatorzy późnego Cesarstwa Rzymskiego, s. 31; M. Simonetti, La crisi, s. 323-325, podkreśla, że potępiono na nim anomejczyków, czyli właśnie pod względem doktrynalnych właściwych arian; D. Spychała, Cesarze, s. 36-40, 114, 178-180. 
$\mathrm{kami}^{10}$. W związku $\mathrm{z}$ tym to ich powtórnie przyjmowano do Kościoła, a nie rzekomych arian. W połowie IV w. homeizm był też herezją, gdyż odrzucał nicejską współistotność, ale nie miał on większego związku z nauką Ariusza ${ }^{11}$.

Na s. 130, omawiając z kolei próby nawiązania kontaktów pryscylian z papieskim Rzymem, autor porównuje odmowę przyjęcia hiszpańskiej delegacji przez Damazego do takiej samej sytuacji, tym razem z udziałem biskupa Rzymu Syrycjusza i św. Paulina z Noli ${ }^{12}$. Widząc niezręczność tego porównania, sam Krzysztof Sordyl w przypisie 179 zauważa, że Paulina z Pryscylianem łączyły przede wszystkim ich arystokratyczne pochodzenie i asceza, choć i to nie do końca musiało być prawdą, gdyż należy pamiętać o oskarżeniach na temat niemoralnego życia hiszpańskiego hierarchy. Nie oznacza to wcale, że Paulin popierał naukę pryscylian.

Podobne niezręczności przydarzyły się autorowi przy okazji powrotu do przedstawiania wydarzeń politycznych. O dziwo, tym razem udało mu się (s. 132-133) ukazać zgodnie z faktami przebieg początków uzurpacji Maksymusa i działań zbrojnych będących skutkiem tych wydarzeń ${ }^{13}$. Jednak opisując sytuację na dworze Walentyniana II, autor stwierdził, że Mediolan był pod kontrolą wspomnianego cesarza "jego matki Justyny i żołnierza Bauto". Jak powszechnie wiadomo, żołnierz to najniższy rangą członek sił zbrojnych, także rzymskich, w tym wypadku autorowi chodziło prawdopodobnie o ogólne określenie terminu „wojskowy”, którym był istotnie ten Germanin (Frank). Jako że w bibliografii do swojej monografii Krzysztof Sordyl zamieścił pracę Zosimosa, w tłumaczeniu H. Cichockiej i z komentarzem E. Wipszyckiej, mógł on na s. 46, 231, 233, 253, 266 znaleźć informację, że ów Bauto (Bauton) lub Flawiusz Bauto to zdaniem Wipszyckiej wódz rzymski noszący tytuł magister militum, który później został konsulem w 385 r. i teściem Arkadiusza, dziadkiem Teodozjusza $\mathrm{II}^{14}$. Niefrasobliwe użycie przez autora określenia pozycji wspomnianego germańskiego dostojnika wydaje się dużym nieporozumieniem lub wynika $\mathrm{z}$ niezrozumienia przez niego istniejącej w ówczesnym Cesarstwie hierarchii społecznej i wojskowej.

${ }^{10}$ Ariminum (359) can. 1, 3-11; Soc. II. 37; Soz. IV. 23-24; Teod. HE, II. 18-20, 22-23; S. Bralewski, Imperatorzy późnego Cesarstwa Rzymskiego, s. 31; M. Simonetti, La crisi, s. 323-325; D. Spychała, Cesarze, s. 36-40, 114, 178-180.

${ }_{11}^{1}$ J. Martin, Spätantike und Völkerwanderung, s. 17-21, 149, 154; D. Spychała, Cesarze, s. 36-40.

${ }^{12}$ J. Martin, Spätantike und Völkerwanderung, s. 117, 119, 204; S. Mazzarino, Storia sociale del vescovo Ambrogio, s. 48, 51-52.

${ }^{13}$ J. Martin, Spätantike und Völkerwanderung, s. 36, 117, 119.

${ }^{14}$ Soc. HE, V. 12; R. Haehling von Lanzenauer, Die Religionszugehörigkeit, s. 459, 461, 463, 570, 576, 578-579, podkreśla, że był on zdeklarowanym poganinem; J.N.D. Kelly, Hieronim. Życie, pisma, spory, tłum. R. Wiśniewski, Warszawa 2003, s. 206; J. Martin, Spätantike und Völkerwanderung, s. 36, zauważa, że był on z pochodzenia Frankiem. 
Nie do końca jest też jasne, czy autor zdaje sobie sprawę, że ów Walentynian II, który rzekomo kontrolował w interesującym nas czasie Mediolan, miał w momencie śmierci swego przyrodniego brata Gracjana dopiero dwanaście lat i na pewno nie miał żadnej kontroli nad sprawami o charakterze politycznym i militarnym ${ }^{15}$. Sordyl uważa, prawdopodobnie słusznie, że dojście do władzy Maksymusa zmieniło położenie samego Pryscyliana, który dotychczas potrafił sobie zapewnić mniej czy bardziej oficjalne poparcie dla swojej działalności na dworach Gracjana i Walentyniana II. Jak podkreślają zgodnie badacze, np. Aleksander Demandt i Kazimierz Ilski, nowy cesarz określał się pod względem religijnym nie tylko jako chrześcijanin, ale wprost jako gorliwy nicejczyk, o czym może świadczyć zdaniem tego ostatniego zwołanie przez niego synodu w Bordeaux skierowanego przeciw Pryscylianowi ${ }^{16}$.W nowych warunkach hiszpański hierarcha stał się bowiem osobą podejrzaną, którą czekał proces za uprawianie magii przed przedstawicielami nowej władzy ${ }^{17}$. W miarę prawidłowo przedstawił autor także udział biskupa Mediolanu, Ambrożego, w tej sprawie, co nie znaczy jednak, że nie ustrzegł się przy tej okazji pewnych niedomówień i przeinaczeń. Prawidłowo, czyli w przedziale czasowym między 385 a 387 r., umieścił wydarzenia związane z procesem i egzekucją Pryscyliana ${ }^{18}$. Natomiast przedstawiając audiencję Ambrożego u Maksymusa, autor, opierając się przede wszystkim na listownej relacji mediolańskiego hierarchy wysłanej do Walentyniana, zauważył, że w czasie rozmów doszło do incydentu, w którego rezultacie uzurpator wyrzucił (lub miał wyrzucić) biskupa z pałacu ${ }^{19}$. Należy jednak pamiętać o tym, że Ambroży był

${ }^{15}$ P. Diak. XI, 7, zauważa bardzo młody wiek nowego władcy; Zos. His. IV, 19, podaje, że w momencie wyniesienia do godności augusta Walentynian II miał pięć lat; S. Bralewski, Walentynian II, [w:] J. Prostko-Prostyński, S. Bralewski, M.J. Leszka, M. Kokoszko (red.), Słownik cesarzy rzymskich, Poznań 2001, s. 293, sugeruje, że w momencie wyniesienia do godności augusta Walentynian II miał cztery lata (urodzony jesienią $371 \mathrm{r}$., augustem mianowano go 22 XI $375 \mathrm{r}$.); A. Demandt, Die Spätantike, s. 125-126, 129; K. Ilski, Idea jedności politycznej, społecznej i religijnej, s. 114, podaje, że w 381 r. Walentynian miał dwanaście lat; J. Martin, Spätantike und Völkerwanderung, s. 35-36.

${ }^{16}$ A. Demandt, Die Spätantike, s. 460; K. Ilski, Idea jedności politycznej, społecznej i religijnej, s. 120.

${ }^{17}$ A. Demandt, Die Spätantike, s. 460; K. Ilski, Idea jedności politycznej, społecznej i religijnej, s. 120 , przyp. 28.

${ }^{18}$ G. Clark, Christianity and Roman society, s. 99, podaje, że do procesu Pryscyliana biskupa Avilii doszło w 385 r. za panowania Gracjana, co wydaje się znaczącą pomyłką autorki; A. Demandt, Die Spätantike, s. 460, zauważa, że do procesu Pryscyliana doszło w 385 r.; M.J. Leszka, Magnus Maksymus, [w:] J. Prostko-Prostyński, S. Bralewski, M.J. Leszka, Słownik cesarzy rzymskich, s. 304-305; J. Martin, Spätantike und Völkerwanderung, s. 117, 119; S. Mazzarino, Storia sociale del vescovo Ambrogio, s. 52-53; P. Nowak, Komentarz, [w:] Św. Ambroży z Mediolanu, Listy, 1, tłum. idem, Kraków 1997, s. 227, przyp. 33, podaje, że do procesu i egzekucji Pryscyliana doszło wiosną 385 r.; S. Rebenich, Hieronymus und sein Kreis, s. 35, 66.

${ }^{19}$ Amb. Ep. 30, 12. 
członkiem oficjalnego poselstwa Walentyniana II do Maksymusa i takie postępowanie byłoby jednoznaczne $\mathrm{z}$ wypowiedzeniem wojny, do czego jednak $\mathrm{w}$ tym roku nie doszło ${ }^{20}$.Wydaje się więc, że pogląd Krzysztofa Sordyla jest nadinterpretacją listownego zapisu, który podaje wprost, że chodziło jedynie o stanowczy nakaz opuszczenia siedziby Maksymusa, a nie o nagłe usunięcie, co sugerowałby wspomniany wcześniej termin ${ }^{21}$. Autor dalej słusznie ukazuje powody takiego postępowania biskupa Mediolanu, ale zapomina wyciągnąć wszystkie wnioski $z$ tego, że informacje na ten temat czerpiemy przede wszystkim $\mathrm{z}$ korespondencji urzędowej samego Ambrożego ${ }^{22}$. Choć wbrew zdaniu autora to nie adresat (czternastoletni władca) był prawdziwym odbiorcą wysłanych informacji (właściwie miały one przekonać cesarzową Justynę i jej doradców o nieugiętości cesarskiego wysłannika), to i tak celem takiej korespondencji z reguły nie jest przedstawianie rzeczywistego przebiegu wypadków, ale ukazanie nadawcy listu w jak najlepszym świetle. Ciekawe, że biograf Ambrożego, Paulin z Mediolanu, przedstawił opisywane wydarzenia w odmienny sposób: dzielny biskup nie tylko ekskomunikuje uzurpatora cesarskiej godności, ale także nakłania go do złożenia nieprawnie przejętej władzy ${ }^{23}$. Można wnosić, że dla Paulina potępianie przez Ambrożego kolejnych cesarzy rzymskich stało się już swego rodzaju toposem.

Konsekwentnie należy mieć również zastrzeżenia do wywodu autora ze s. 144, kiedy to po raz kolejny podkreśla on takie relacje między Ambrożym a Walentynianem, jakby ten drugi pełnił rzeczywiście (a nie tylko nominalnie) najwyższą władzę w państwie. Nie był on jednak w tym czasie, mając czternaście lat (maksymalnie szesnaście), osobą podejmującą najważniejsze decyzje, co było dalej zarezerwowane dla Justyny i jej otoczenia ${ }^{24}$.

Prawdopodobnie wynikiem nie do końca wystarczającej znajomości autora religijnych realiów IV w. wydaje się kolejne na s. 145 przedstawienie konfliktów nicejsko-homejskich w Mediolanie tak, jakby dotyczyły one arianizmu, który jednak w swojej podstawowej wersji doktrynalnej (anomeizm) raczej $\mathrm{w}$ tym

${ }^{20}$ Amb. Ep. 30, 12; A. Demandt, Die Spätantike, s. 460; K. Ilski, Idea jedności politycznej, społecznej i religijnej, s. 120, przyp. 28.

${ }^{21}$ Amb. Ep. 30, 12: Maksymus zgodnie z relacją Ambrożego rozkazał, by biskup „natychmiast odszedł”. Wydaje się, że jest to wersja łagodniejsza od brutalnego wyrzucenia, jak sugeruje K. Sordyl; Paul. Vita, 19, S. Mazzarino, Storia sociale del vescovo Ambrogio, s. 54-57.

${ }^{22}$ Amb. Ep. 30, 12.

${ }^{23}$ Paul. Vita. 19: z przekazu Paulina wynika, że Ambroży ekskomunikował Magnusa, który pokutując, złożył piastowany urząd, co nie wydaje się zgodne z rzeczywistością historyczną; K. Ilski, Idea jedności politycznej, społecznej i religijnej, s. 121, zastanawia się, czy Paulin nie dokonał w tym wypadku nadinterpretacji i rozciągnął nałożoną na cześć biskupów anatemę na samego Magnusa.

${ }^{24}$ Ibidem, s. 119-121. 
okresie nie występował masowo na terenie Półwyspu Apenińskiego ${ }^{25} . \mathrm{Z}$ kolei przy omawianiu wytyczonych Pryscylianowi zarzutów autor dość niefrasobliwie zauważył na s. 148, że:

(...) nie wydaje się, żeby bycie manichejczykiem $\mathrm{w}$ tym czasie stanowiło samo w sobie poważne zagrożenie dla czyjegoś życia. Manichejczycy ukrywali się, jak zauważa Augustyn, ale aż do czasów Anastazjusza i Justyniana nie byli nękani egzekucjami.

Fragment „Wyznań” Augustyna, który doprowadził Krzysztofa Sordyla do takich wniosków, nie potwierdza jednak w zdecydowany sposób założonej przez autora tezy ${ }^{26}$. Biskup Hippony stwierdza bowiem, że „Nec eam defendebam pristina animositate, sed tamen familiaritas eorum-plures enim eos Roma ocultabat"27. Tłumaczenie tego fragmentu nie jest, jak wynika z podanych we właściwym przypisie przykładów, do końca rozstrzygające, gdyż możliwe są różne jego interpretacje. Podobnie status prawny samych manichejczyków istotnie nie wydaje się w interesującym nas okresie jasny, gdyż balansuje on między uznawaniem ich za wyznawców odrębnej od chrześcijaństwa religii a za jego nieortodoksyjny odłam (sektę) $)^{28}$. Fakt jednak, że tacy prawdopodobni manichejczycy jak Sebastian dochodzili do najwyższych godności w rzymskiej armii, natomiast rozmowy między Augustynem a prominentnymi dostojnikami manichejskiej wspólnoty religijnej odbywały się publicznie na miejskich rynkach, sugeruje raczej brak w tym okresie zorganizowanych prześladowań uczniów Manesa ${ }^{29}$. Krzysztof Sordyl zaznaczył dalej na s. $148 \mathrm{w}$ przypisie 245, że „kara śmierci dla manichejczyków została ustanowiona za rządów władcy Anastazjusza. Edykty Justyniana winny ulec absolutnemu zniszczeniu”. Nie negując prawdziwości tych informacji, niestety należy zauważyć, że recenzent nie wie, o co chodzi autorowi

${ }^{25}$ R. Sörries, Auxentius und Ambrosius, s. 10-11, 20-21, 33-45: uważa, że Ambroży rywalizował w Mediolanie z arianami; zob. np. H.Ch. Brennecke, Studien zur Geschichte der Homöer. Der Osten bis zum Ende der homöischen Reichskirche, Beiträge zur historischen Theologie; 73, Tübingen 1988; D. Spychała, Cesarze, s. 127-129; M. Stachura, Heretycy, s. 70-80.

${ }^{26}$ Aug. Conf. V. 10, 19.

${ }^{27}$ Aug. Conf. V. 10, 19: „Wprawdzie nie broniłem już jej z dawnym zapałem, ale bliska zażyłość z jej wyznawcami - Rzym kryje wielką ich ilość” (tłum. Z. Kubiak); bliżej sensu wykorzystanego przez K. Sordyla byłby tekst w tłumaczeniu J. Czuja: „Nie broniłem już wprawdzie tej nauki z dawnym zapałem, ale zażyłość z nimi - w Rzymie ukrywała się znaczna ich ilość”. W pierwszym przypadku tłumacz sądzi, że Augustyn zauważył, iż manichejczycy funkcjonują w anonimowym miejskim tłumie, natomiast drugie tłumaczenie istotnie sugeruje, że Augustyn zakładał celowe ukrywanie się przedstawicieli tej grupy wyznaniowej w Wiecznym Mieście.

${ }^{28}$ CT. XVI.5.7; XVI. 5, 9; XVI. 7, 3; M. Stachura, Heretycy, s. 88.

${ }^{29}$ At. Apol. fug. 6; Idem, HA, 59-60; P. Brown, Augustyn, s. 36-55; M. Stachura, Heretycy, s. 70, przyp. 9, podaje, że przynależność Sebastiana do tej wiary wydaje się kalumnią Atanazego, 88, 117-119. 
w drugim z zacytowanych zdań ${ }^{30}$. Pewien problem jest również z sektami enkratytów i akwarian, które zdaniem autora sympatyzowały $\mathrm{z}$ manicheizmem. $\mathrm{W}$ tym wypadku należy się jednak zgodzić ze zdaniem Michała Stachury, który zauważa, że sekty „enkratyków, apotaktytów, hydroparastów i sakkoforów” to różne nazwy odnoszące się do jednego Kościoła enkratyków, którego wyznawców nic właściwie nie łączyło $\mathrm{z}$ manicheizmem $\mathrm{z}$ wyjątkiem praktykowania gorliwej ascezy, która nie jest przecież zarezerwowana wyłącznie dla manichejczyków ${ }^{31}$. Podobnie trudno zrozumieć, o jakiej to na s. 150 i 151 inkwizycji pisze autor w kontekście wydarzeń z końca IV w. Tekst ze s. 151 jest niby jasny: „Marcin wystąpił z petycją do Maksymusa, żeby odwołać wysłaną już do Hiszpanii inkwizycję w celu odnalezienia zwolenników Pryscyliana". Wyraz inquisitio (inkwizycja) oznacza w języku łacińskim: poszukiwanie, badanie, śledztwo, trudno w tym miejscu nie skojarzyć jednak tego terminu $\mathrm{z}$ instytucją kościelną działającą w średniowieczu i niemającą nic wspólnego z omawianymi wyżej wydarzenia$\mathrm{mi}^{32}$. Dla jasności swego wywodu autor powinien to przewidzieć i wyjaśnić, o jaką inkwizycję mu chodziło. Natomiast należy przyznać rację autorowi w kwestii porównania stanowiska donatystów wobec katolików z podobnym tłumaczeniem na tej samej stronie w przypisie 263 do odnoszenia się pryscylian do biskupów katolickich zamieszanych w sprawę Pryscyliana, a przekazujących święcenia i charyzmaty swoim następcom ${ }^{33}$.

Pewne problemy interpretacyjne budzi również ostatni podrozdział drugiego rozdziału omawianej pracy, poświęcony dziejom pryscylianizmu do 572 r. Autor nie przedstawił bowiem własnej hipotezy na temat funkcjonowania pryscylian po śmierci założyciela. W tym okresie wspólnoty chrześcijańskie (i nie tylko one) opierały się właściwie na dwóch podstawowych modelach organizacji wewnętrznej. Manichejczycy, marcjonici, montaniści czy donatyści stworzyli scentralizowane struktury, natomiast nicejczycy (Kościół Powszechny), homejczycy, macedonianie i prawdopodobnie anomejczycy kontynuowali tradycyjną episkopalną strukturę, z której dopiero powoli zaczynał się kształtować system metropolii i patriarchatów z symbolicznym przewodnictwem następcy św. Piotra na czele (w przypadku nicejczyków) ${ }^{34}$. Krzysztof Sordyl jedynie sugeruje, że pewien wpływ na kształtowanie się pryscyliańskiej wspólnoty mógł mieć kult jej założy-

\footnotetext{
${ }^{30}$ A. Demandt, Die Spätantike, s. 201-202, 466-469.

${ }^{31}$ M. Stachura, Heretycy, s. 88-89.

${ }^{32}$ P. Seifert, Wstęp, [w:] B. Gui, Księga inkwizycji, tłum. M. Pawlik, J. Zychowicz, Kraków 2002, s. 21, podaje, że w południowej Francji narodziny inkwizycji miały miejsce w $1231 \mathrm{r}$.

${ }^{33}$ W.H.C. Frend, The Donatist Church. A movment of protest in Roman North Africa, Oxford 1985, s. 97-101, 146-179; D. Spychała, Przemiany, 2, s. 415-418.

${ }^{34}$ Ibidem, s. 355-417.
} 
ciela, a ważną rolę w jej budowaniu spełniał jego grobowiec. Nie posuwa to jednak naprzód dyskusji na temat kształtu organizacyjnego, a nawet samego ewentualnego istnienia odrębnego Kościoła pryscyliańskiego.

Autor ma także problemy ze strukturą organizacyjną Kościoła Powszechnego i z rolą biskupa Rzymu, gdyż inaczej nie sugerowałby, że w tym okresie mogły się odbyć synod generalny hiszpańskich prowincji albo lokalne zgromadzenie biskupów w Galicji pod przewodnictwem następcy św. Piotra. Biskupi Wiecznego Miasta co najwyżej przewodniczyli obradom biskupów ich własnej prowincji kościelnej, w pozostałych przypadkach reprezentowali ich legaci, co miało wyrażać przyjęte nad Tybrem stanowisko o dominacji papieża nad pozostałymi biskupami i zgromadzeniami synodalnymi ${ }^{35}$. Podobnie dyskusyjna jest przynależność wyznaniowa Wizygotów, Swebów i Wandalów, których np. na s. 169 i 170-171 autor nazywa arianami. Dla znawcy problemów religijnych czwartego i piątego wieku, kim niewątpliwie jest autor omawianej monografii, powinno być oczywiste, że używane przez niego pojęcie nie jest adekwatne do prawdziwych poglądów religijnych wymienionych ludów ${ }^{36}$. Pod względem wyznaniowym byli oni z reguły homejczykami, choć zdarzali się też tacy, którzy byli anomejczykami. Wyznawcy pierwszego odłamu nie byli arianami ${ }^{37}$.

W trzecim rozdziale Krzysztof Sordyl zajął się doktryną pryscyliańską, a szczególnie zawartą w niej ideą Boga. Przy tej okazji ponownie na s. 198 i 238 oraz 261 przedstawia poglądy doktrynalne arian bez zaznaczenia, o jakiej grupie występującej w źródłach z epoki pod tą nazwą jest mowa. Na s. 238 pojawiają się dość niespodziewanie macedonianie, o których można było wspomnieć, że byli oni przeciwnikami boskości Ducha Św. i należeli do szeroko pojętego obozu antynicejskiego, który w źródłach nosił często miano arianizmu ${ }^{38}$. Natomiast na s. 244, może z powodu miejsca umieszczenia tej informacji, autor podaje, że w okresie życia Pryscyliana arianizm był rozpowszechniony w Hiszpanii, co jest pomyłką, gdyż plemiona germańskie wyznające nauki antynicejskie (a nie ariańskie) pojawiły się na Półwyspie Pirenejskim dopiero na początku V w. ${ }^{39}$

${ }^{35}$ K. Schatz, Prymat papieski od początków do współczesności, tłum. E. Marszał, J. Zakrzewski, Kraków 2004, s. 17-59; idem, Sobory powszechne. Punkty zwrotne w historii Kościoła, tłum. J. Zakrzewski, Kraków 2001, s. 15-61.

${ }^{36}$ D. Spychała, Cesarze, s. 36-42, 205-230, 256-259.

${ }^{37}$ A. Demandt, Die Spätantike, s. 98, przyrównuje homeizm do arianizmu, co jest zbytnim uproszczeniem tego ruchu; D. Spychała, Cesarze, s. 26-40; J. Strzelczyk, Goci, s. 105, 106; idem, Wandalowie i ich afrykańskie państwo, Warszawa 1992, s. 239-241, podaje ogólnie, że Goci i Wandalowie przyjęli chrześcijaństwo w wersji ariańskiej.

${ }^{38}$ Hasło: Macedoniusz I, [w:] J.M. Szymusiak, M. Starowieyski, Słownik Wczesnochrześcijańskiego Piśmiennictwa, St.MCh 2; Poznań 1971; D. Spychała, Cesarze, s. 40-44.

${ }_{39}$ P. Diak. HR, XII. 12-15; XIII. 1-5; A. Demandt, Die Spätantike, s. 142-147. 
Podobnie dokładności wymagałoby podkreślenie (s. 248), że Marceli z Ancyry został wygnany za panowania Konstantyna Wielkiego, czyli w 336 r., a jego rehabilitacja była uznawana jedynie przez nicejczyków i to nie wszystkich ${ }^{40}$. Również doprecyzowania wymaga przypis 264 ze s. 252, w którym przedstawione zostały poglądy i działalność Apolinarego z Laodycei ${ }^{41}$. Przy Fotynie natomiast na s. 258 powinno się dodać, że był on nicejskim biskupem Sirmium, który pod wpływem prawdopodobnie nauk Marcelego z Ancyry zaczął głosić heretyckie poglądy ${ }^{42}$. Należy się jednak zgodzić z Krzysztofem Sordylem, że doszukiwanie się w nauce Pryscyliana wpływów ariańskich nie jest sprawiedliwe dla hiszpańskiego hierarchy.

W rozdziale czwartym autor poruszył problem idei człowieka i świata w doktrynie Pryscyliana. Dokonuje w nim ponownie podziału na w miarę ortodoksyjną naukę hiszpańskiego biskupa i na ulegającą wpływom manichejskim drugą generację jego zwolenników. Niewątpliwie można się zgodzić z takim stanowiskiem, choć w kolejnym, piątym rozdziale, poświęconym aspektowi astrologicznemu nauki Pryscyliana, autor na s. 305 podaje informacje o wpływach tejże pseudonauki na doktrynę wspomnianego hierarchy, co zmienia przyjęte wcześniej przez Sordyla założenie. Przy okazji omawiania problemu aniołów w nauce Pryscyliana autor bez komentarza pozostawia informację, że Maria Magdalena jest dla gnostyków partnerką seksualną Jezusa, a Mariamne, Marianne lub Mariamme siostrą apostoła Filipa ${ }^{43}$. Pozostawienie takich wiadomości bez ukazania stanowiska nauki w tej sprawie budzi pewne zdziwienie.

Jak wynika z przedstawionych zastrzeżeń, praca Krzysztofa Sordyla mimo swoich niewątpliwych plusów (np. jasność wywodów o charakterze teologicznym) nie do końca ukazała złożony problem pryscylianizmu. Udało się jednak autorowi przedstawić w miarę kompletnie postać samego Pryscyliana i jego

\footnotetext{
${ }^{40}$ Hier. Vir. ill. 86; Hasło: Marceli z Ancyry, [w:] Słownik Wczesnochrześcijańskiego Piśmiennictwa, s. 275.

${ }^{41}$ Hier. Vir. ill. 104; Hasło: Apolinary z Laodycei, [w:] Słownik Wczesnochrześcijańskiego Piśmiennictwa, s. 43-44; D. Spychała, Apolinary z Laodycei a kontrowersja ariańska, UG 33-34/ 2007, s. 54-61.

${ }^{42}$ Hier. Vir. ill. 107; Hasło: Fotyn z Syrmium, [w:] Słownik Wczesnochrześcijańskiego Piśmiennictwa, s. 161-162.

${ }^{43}$ Hasło: Filip, [w:] W.R.F. Browning, Słownik biblijny, tłum. J. Slawik, KŚRM 9, Warszawa 2009, s. 157-158; G. Herrgott, Hasło: Maria Magdalena, [w:] A. Grabner-Haider, Praktyczny Słownik Biblijny, tłum. T. Mieszkowski, P. Pachciarek, Warszawa 2016, s. 703; F. Gryglewicz, Hasło: Filip Apostoł, [w:] EK, 5, Lublin 1989, col. 202-203; idem, Hasło: Filip Diakon, [w:] EK, 5, col. 205; Hasło: Maria Magdalena, [w:] Słownik biblijny, s. 308; A. Meister, Hasło: Maria, [w:] PSB, s. 703; S. Szymik, Hasło: Maria Magdalena, [w:] EK, 11, Lublin 2006, col. 1319-1320; A. Welburn, Maria Magdalena. Prawda, legendy i kłamstwa, tłum. K. Bednarek, Radom 2006; K. Zisler, Hasło: Maria z Betanii, [w:] PSB, s. 703.
} 
doktryny. Szkoda, że tytuł omawianej pracy nie został ograniczony do takiej treści. Największym mankamentem recenzowanej monografii jest zbyt duża, jak na tak dobrego autora, liczba błędów o charakterze podstawowym i to nie tylko $\mathrm{z}$ dziedziny historii starożytnej, ale także z teologii.

Jeżeli chodzi o pracę redakcyjną, to należy zaznaczyć, że po raz kolejny w publikacji wydawnictwa WAM pojawiły się przypisy w wersji niezbyt uporządkowanej. Bibliografia także ma swoje mankamenty, np. na s. 386 wśród spisu opracowań naukowych pojawia się niespodziewanie „Martini episcopi Bracarensis opera omnia”, C.W. Barlow (red.) ${ }^{44}$, New Haven 1950, czyli praca jak najbardziej źródłowa. Mimo to uważam, że po koniecznych poprawkach monografia Krzysztofa Sordyla zajmie należne jej miejsce wśród polskich publikacji historycznych z dziedziny wczesnego chrześcijaństwa.

${ }^{44}$ Zapis oryginalny. 